\title{
ANALISIS PUTUSAN MAHKAMAH KONSTITUSI NOMOR 22/PUU-XV/2017 TENTANG BATAS USIA NIKAH BAGI PEREMPUAN
}

\author{
Rafiah Septarini \\ Guru di Pondok Pesantren Hidayatullah Tenggarong Kaltim \\ rafiah.septahid@gmail.com \\ Ummi Salami \\ STIS Hidayatullah Balikpapan \\ ummiSalami@gmail.com
}

\begin{abstract}
Abstrak
Hukum positif Indonesia membedakan batasan minimal umur nikah antara laki-laki dan perempuan, perbedaan ini dinilai menimbulkan polemik. Olehnya, UndangUndang No. 1 Tahun 1974 tentang Perkawinan digugat dan diuji di depan sidang Mahkamah Konstitusi. Penelitian ini bertujuan untuk mengetahui landasan Pemohon mengajukan judicial review dan Pertimbangan Mahkamah Konstitusi Dalam Putusan Nomor 22/PUU-XV/2017.Penelitian ini merupakan penelitian kepustakaan (library research) dengan menggunakan pendekatan kualitatif. Hasil penelitian menyimpulkan bahwa alasan para Pemohon adalah karena terlanggarnya hak anak yang meliputi kesehatan, pendidikan, eksploitasi anak dan perbedaan usia nikah di negara lain. MK mengabulkannya permohonan para Pemohon karena Pasal 7 ayat (1) telah menimbulkan diskriminasi atas dasar jenis kelamin yang berdampak pada tidak terpenuhinya hak anak perempuan sebagai bagian dari hak asasi manusia yang telah di jamin dalam Undang-Undang Dasar 1974.
\end{abstract}

Keywords: judicial review, batas usia nikah, mahkamah konstitusi, UndangUndang Pernikahan

\section{A. Pendahuluan}

Nash Alquran dan Sunnah tidak menjelaskan secara rinci umur berapa batas minimal usia dibolehkannya seseorang menikah. Al-Quran menentukan batasan kebolehan menikah apabila dia telah dewasa dengan indikasi matangnya jiwa dan telah mengalami mimpi basah bagi laki-laki dan keluarnya darah haid bagi perempuan.

Hal ini menyebabkan para ulama berbeda pendapat dalam menentukan batas usia menikah. Menurut ulama Syafi'iyyah batas minimal usia dewasa adalah pada saat usia 15 tahun bagi laki-laki maupun perempuan. Sedangkan Menurut Imam Abu Hanifah batas usia kedewasaan adalah 18 tahun bagi laki-laki dan 17 
tahun bagi perempuan. ${ }^{1}$

Menurut hukum Indonesia, membedakan antara laki-laki dan perempuan dalam batasan minimal umur nikah. Undang-Undang No. 1 Tahun 1974 pada Pasal 7 ayat (1) menyebutkan: "Perkawinan hanya diizinkan apabila pihak laki-laki telah berusia 19 tahun dan pihak perempuan telah berusia 16 tahun." 2

Perbedaan tersebut menyebabkan Undang-Undang No. 1 Tahun 1974 tentang Perkawinan digugat (Judicial Review) di Mahkamah Konstitusi oleh Endang Wasrinah, Maryanti, dan Rasminah. Alasan para Pemohon sepanjang usia 16 (enam belas) tahun telah melanggar hak konstitusional dengan prinsip "kesamaan bagi kedudukan hukum di depan hukum untuk seluruh warga negara, baik selaku pribadi maupun statusnya sebagai pejabat negara" atau dikenal dengan prinsip Equality before the Law ${ }^{3}$ dan hal itu berdasarkan ketentuan Pasal 27 ayat (1) UUD 1945. Para Pemohon juga menggabungkan Undang-Undang Perlindungan Anak untuk menguatkan gugatannya: "Orangtua berkewajiban dan bertanggung jawab untuk, Mencegah terjadinya pernikahan pada usia anak-anak." ${ }^{4}$

Undang-undang Perlindungan Anak dalam Pasal 26 ayat (1) di atas menegaskan bahwa orangtua memiliki kewajiban untuk mencegah anaknya untuk menikah apabila masih di bawah usia kematangan dan usia anak yang di maksud dalam UU Perlindungan Anak ini adalah anak yang berusia di bawah usia 18 tahun. ${ }^{5}$

Berlakunya Pasal 7 ayat (1) Undang-Undang Perkawinan ini juga telah membuat orangtua yang miskin merasa wajib menikahkan seorang anak perempuannya agar tidak menjadi beban keluarga. Melihat kenyataan yang di alami para Pemohon setelah menikah tidak mengubah kemiskinan itu, dan hasil dari pernikahan tersebut seorang anak perempuan tidak bisa bekerja dikarenakan tidak sekolah hingga tuntas.

Berdasarkan alasan-alasan para Pemohon di atas, Mahkamah Konstitusi menerima sebagian alasan para Pemohon, seperti menyatakan bahwa UU No. 1 Tahun 1974 bertentangan dengan UUD 1945 dan tidak tidak mempunyai kekuatan hukum mengikat dan menyatakan bahwa perempuan menikah setara dengan lakilaki. Putusan MK di atas memiliki implikasi terhadap perempuan yang apabila batas

${ }^{1}$ Muhammad Husain, Fiqh Perempuan (Yogyakarta: Liks, 2001), 68. Google Book.

2 Nuruddin, Amir dan Azhari Akmal Taringan, Hukum Perdata Islam Indonesia: Studi Kritis Perkembangan Hukum Islam Dari Fikih, UU/1974 Sampai KHI (Jakarta: Prenadamedia Group, 2016), Cet. ke-6, 2.

3 Ibid., 15

4 Undang-Undang Republik Indonesia Nomor 35 Tahun 2014 Tentang Perubahan Atas Undang-Undang Nomor 23 Tahun 2002 Tentang Perlindungan Anak, diakses pada 07 Januari 2019. www.hukumonline.com. Adobe PDF eBook.

5 Ibid. 
usia dinaikkan menjadi 19 tahun, maka usia perempuan akan semakin tinggi dan semakin lama untuk menunggu waktu untuk menikah dan akhirnya akan banyak kemaksiatan berupa perzinaan yang merajalela di Indonesia.

Umat Islam merespon putusan MK dengan diwakili oleh Majelis Ulama Indonesia (MUI). MUI bertentangan dengan putusan MK dikarenakan akan menjadi sebuah polemik atau masalah baru dan suatu saat nanti akan ada ruang untuk mengubah Undang-Undang No. 1 Tahun 1974 pada Pasal lainnya di kemudian hari. Wakil ketua MUI Zainut Tauhid Saadi sehari setelah keputusan MK menyatakan bahwa "Undang-Undang Perkawinan memiliki sejarah yang sangat tinggi dan ikatan emosional dengan ummat Islam, sehingga mengimbau kepada semua pihak untuk bersikap arif dan berhati-hati jika berniat untuk mengubahnya."6

\section{B. Metode Penelitian}

Penelitian ini merupakan penelitian hukum normatif (legal research). Penelitian hukum normatif adalah penelitian hukum di dalam wilayah ilmu hukum sendiri dalam artiannya yang luas. Menurut Sarjono Sukanto mengatakan bahwa penelitian hukum yang dilakukan dengan cara meneliti bahan pustaka atau data sekunder belaka dapat dinamakan penelitian hukum normatif atau penelitian hukum kepustakaan (Library legal study). ${ }^{7}$

Penelitian ini bersifat deskriftif analitik dalam artian bahwa penelitian ini menyusun dan mengumpulkan data dengan menguraikan alasan putusan mahkamah konstitusi nomor 22/PUU-XV/2017 tentang batas usia nikah bagi perempuan.

Sumber data yang peneliti gunakan dalam penelitian ini adalah sebagai berikut:

a. Sebagai sumber primer yaitu dokumen berupa Putusan Mahkamah Konstitusi Nomor 22/PUU-XV/2017.

b. Sumber hukum sekunder yaitu data tambahan yang mendukung buku primer, baik dari buku, internet, skripsi dan sumber informasi yang akurat dan dapat dipertanggungjawabkan.

c. Sumber tersier yaitu data tambahan yang mendukung buku primer dan sekunder seperti kitab-kitab fiqih tentang pernikahan dan wanita.

Proses pengumpulan data dilakukan melalui penelusuran literatur-literatur yaitu dengan mengkaji dan menelaah beberapa bahan pustaka yang memiliki

6 MUI Sebut Putusan MK Menimbulkan Polemik. diakses pada 20 Desember 2018. http://www.radarcirebon.com. Adobe PDF eBook.

${ }^{7}$ Nurul Qomar, dkk. Metode Penelitian Hukum (Legal Research Methods). (Makassar: CV. Sosial Politic Genius, 2017), 49. 
relevansi dengan tema bahasan. Adapun referensi yang menjadi bahan acuan primer dalam menyusun skripsi ini adalah Putusan Mahkamah Konstitusi Nomor 22/PUU$\mathrm{XV} / 2017$. Sedangkan data sekunder di dapat dari kitab-kitab fiqih dan buku-buku yang terkait dengan bahasan ini.

Metode analisis data ini menggunakan metode content analisis adalah menganalisis alasan Pemohon mengajukan Uji Materi Pasal 7 ayat (1) UUP No. 1 Tahun 1974 dan Pertimbangan Mahkamah Konstitusi dalam Putusan Mahkamah Konstitusi Nomor 22/PUU-XV/2017.

\section{Batas Usia Nikah}

\section{Menurut Hukum Islam}

Islam mensyariatkan seseorang mencari pasangan hidup sesuai yang dia sukai dan tanpa ada paksaan di dalamnya. Islam mensyariatkan seorang calon suami maupun calon istri untuk mencari pasangan hidupnya sesuai dengan kategori atau syarat yang telah ditentukan.

Islam menentukan batas usia untuk seseorang menikah dengan kedewasaan atau baligh dan berakal, kedewasaan yang di maksud adalah apabila seorang lakilaki telah mengalami mimpi basah dan seorang perempuan telah mengalami haid. ${ }^{8}$ Berakal yang di maksud adalah bisa membedakan jalan baik atau buruk yang akan ditempuhnya.

Syariat Islam mewajibkan seorang menikah ketika telah berilmu dalam mengelola kehidupan berumah tangga. Menikah juga diwajibkan apabila calon mempelai siap menghadapi resiko yang akan terjadi setelah menikah.

Usia balig diartikan sebagai seseorang yang bisa melahirkan keturunannya dan dengannya dia bisa menikah. Usia balig menentukan calon mempelai telah bisa diberikan beban seperti melaksanakan hukum agama Islam, baik hukum tersebut bersifat muamalah maupun hudud (ketetapan). ${ }^{9}$

Idealnya calon mempelai menikah adalah saat calon mempelai tersebut telah baligh dan bisa mengarungi kehidupan dengan baik dan perempuan yang akan menjadi istri siap melahirkan keturunan dengan kesehatan yang baik dan kedua mempelai siap melaksanakan hak dan kewajiban masing-masing dengan baik.

Hukum Islam dalam memaknai batasan usia nikah dimulai dari balig. Balig yang di maksud adalah anak laki-laki yang telah melakukan mimpi basah ketika

8 Dadang Hawari, al-Qur'an Ilmu Kedokteran Jiwa dan Kesehatan (Jakarta: Bhakti Prima Yasa, 1996), 252.

9 Muhammad Rasyid Ridha, Tafsir al-ManarJuz I (Mesir: al-Manar, 2000), 397. 
tidur dan dari mimpi tersebut menyebabkan keluarnya air mani ${ }^{10}$ dan dalil balig ini dijelaskan secara tidak langsung oleh Allah swt dalam Q.S an-Nisa' [4]: 6:11

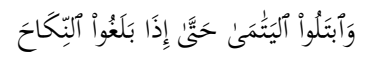

Rasulullah saw juga memberikan penjelasan secara tidak langsung dalam hadits yang diriwayatkan Abdullah Ibn Mas'ud:

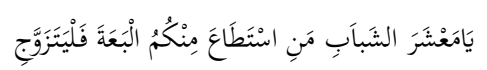

Artinya: "Wahai para pemuda, barangsiapa di antara kalian mampu menyediakan sarana pernikahan, maka hendaklah ia menikah."12

Dalil kedua di atas menyatakan bahwa batas usia nikah ditentukan oleh kemampuan dan kesiapan dalam membangun keluarga. Kemampuan dalam menafkahi dan kesiapan mental dalam menghadapi masalah dalam keluarga dan kedewasaan menentukan keduanya. Kedewasaan yang di maksud adalah telah mengalami usia balig.

Batas usia nikah masih dalam perdebatan para ulama. Para ulama menentukan batas usia nikah dari hal kedewasaan seseorang baik laki-laki maupun perempuan. Menurut ulama Syafi'iyyah batas minimal usia dewasa adalah pada saat usia 15 tahun bagi laki-laki maupun perempuan. Menurut Imam Abu Hanifah batas usia kedewasaan adalah 19 tahun bagi laki-laki dan 17 tahun bagi perempuan. Menurut Imam Malik batas kedewasaan adalah 18 tahun untuk laki-laki dan perempuan. ${ }^{13}$

Imam Abu Hanifah berpendapat bahwa orangtua diperbolehkan untuk menikahkan anak perempuannya yang belum baligh, baik mereka masih gadis maupun seorang janda. Apabila anak tersebut telah balig maka dia boleh memilih menikah dengan siapa yang dia senangi, tanpa meminta persetujuan dari orangtuanya. Posisi orangtua adalah wali jadi tidak boleh menikahkan anak perempuannya tanpa seizinnya apalagi memaksa untuk menikah dengan lelaki yang tidak disenanginya. ${ }^{14}$

Melihat perbendaan pendapat para ulama di atas tentang batas dewasa, dapat dipahami bahwa batas usia dalam menikah tidak disyariatkan dalam al-Qur'an dan hadits secara langsung. Pernikahan yang dilakukan seseorang pasangan yang di

10 Abdullah bin Muhammad, Luhbatut Tafsir Min Ibni Katsir, trans M. Abdul Ghoffar (Jakarta: Imam Syafi'i, 2016), Cet. 9, 300. Cet. Ke-5, 67.

11 Amir Syafruddin, Hukum Perkawinan Islam di Indonesia (Jakarta: Prenamedia Group, 2014),

12 Muhyiddin an-Nawawi, Shohih Muslim (Beirut: Darul Ma'rifah, 1998), No. 3434.

13 Muhammad Husain, Fiqh Perempuan, 68. Google Book.

14 Kamil Muhammad 'Uwaidah, al-Jami' fii Fiqhi an-Nisa', trans. M. Abdul Ghoffar (Jakarta: Pustaka al-Kautsar, 2012), 402. 
bawah usia maupun telah balig dan telah melaksanakan semua rukun dan syarat yang telah ditetapkan oleh Allah maka dihukumi sah dalam syariat Islam.

\section{Menurut Hukum Positif}

Negara Indonesia sejak tahun 1974 telah mengatur dengan baik peraturan dalam hal menikah walaupun peraturan tersebut berlaku untuk segala keyakinan atau agama masing-masing warga negara. 17 tahun kemudian, pemerintah menambah peraturan pernikahan yang dikhususkan atau diwajibkan kepada seorang Muslim untuk taat dan patuh, peraturan tersebut termaktub dalam sebuah Inpres (Instruksi Presiden) Tahun 1991 tentang Kompilasi Hukum Islam.

Dalam Undang-Undang itu disebutkan bahwa batas usia jika pihak laki-laki telah berusia 19 tahun dan pihak perempuan telah berusia 16 tahun. ${ }^{15}$

Menurut hukum Undang-Undang di atas diputuskan batas minimal usia bahwa untuk menjaga kesehatan suami dan istri menurut kesehatan baik jiwa dan raganya supaya calon pasangan suami dan istri bisa membangun rumah tangga dengan baik serta menghasilkan anak yang sehat dan baik dan rumah tangga tersebut tidak berakhir dengan kehancuran atau perceraian. ${ }^{16}$

Batas usia untuk menikah juga telah diatur KHI dan KHI merujuk pada UU No. 1 Tahun 1974 yakni dalam Pasal 15 ayat (2) yang berbunyi: "Bagi calon mempelai yang belum mencapai usia 21 tahun harus mendapat izin sebagaimana yang telah diatur dalam Pasal 6 ayat (2), (3), (4) dan (5) UU No.1 Tahun 1974."17

Tujuan adanya syarat pada Undang-Undang di atas agar kedua calon mempelai tidak bercerai karena kebanyakan pasangan menikah muda bercerai akibat belum mencapai kematangan dalam berfikir sedangkan dalam membangun rumah tangga membutuhkan akal untuk berfikir masa depan keluarganya. ${ }^{18}$

Batas usia nikah dalam Pasal 6 tentang syarat pernikahan menjelaskan bahwa hadirnya syarat tersebut agar tidak ada pernikahan paksa atau gantung dalam kehidupan bermasyarakat. Pernikahan adalah urusan pribadi dan pilihan untuk memilih pasangan sebagai teman hidup dalam membangun kehidupan rumah tangga dan dalam pemilihan ini harus bebas dari paksaan dari pihak manapun. ${ }^{19}$

15 Nuruddin, Amir dan Azhari Akmal Taringan, Hukum Perdata Islam Indonesia: Studi Kritis Perkembangan Hukum Islam Dari Fikih, UU/1974 Sampai KHI, 2.

16 Ibid.

17 Ibid.

${ }_{18}$ Aulia Muthiah, Hukum Islam Dinamika Seputar Hukum Keluarga,63.

${ }^{19}$ Ibid., 65. 


\section{Putusan Mahkamah Konstitusi Nomor 22/PUU-XV/2017}

\section{Pemohon Yang Mengajukan Judicial Review}

Undang-Undang tentang Umur pernikahan digugat oleh tiga orang perempuan yang bernama Endang Wasrinah, Rasminah dan Maryanti. Ketiganya memiliki legal standing melakukan judicial review, mereka dianggap pihak yang hak dan/atau kewenangan konstitutionalnya dirugikan oleh berlakunya undang-undang tersebut. 20

Rasminah berasal dari Indramayu, ia dipaksa menikah saat berusia 13 tahun. Rasminah dipaksa menikah oleh orangtuanya karena faktor ekonomi. Setahun menikah, laki-laki berusia 35 tahun yang menikahinya pergi meninggalkannya tanpa alasan yang jelas. Setelah itu ia dinikahkan lagi dengan laki-laki berusia 25 tahun. "Saya dikawinkan tiga kali, sat usia 13, 16, dan 20 tahun, dan terakhir umur 27 tahun dengan orang yang saya cintai."21

Sama dengan Rasminah, Maryanti dinikahkan oleh keluarganya karena faktor ekonomi. Maryanti dinikahkan pada usia 14 tahun yang saat itu ia belum tamat SD. Dampak fisik yang dialaminya adalah mengalami keguguran sebanyak empat kali lantaran usianya pada saat itu belum siap untuk hamil. "Banyak Pendarahan itu, kalau kata bidan kandungannya lemah, belum boleh seharusnya hamil. Itu sempat empat kali keguguran." 22

Endang Wasrinah menikah saat berusia 14 tahun. Ia menceritakan bahwa tubuhnya sering disuntik KB sehingga menyebabkan demam setiap hari. Pernikahan Endang hanya bertahan selama setahun. Ia menceritakan, "Masih di dalam lingkungan sekolah saya dijemput pulang sama orangtua. Tahu-tahunya di rumah saya dilamar." Alasan orangtuanya menikahkannya karena faktor ekonomi. ${ }^{23}$

\section{Alasan-Alasan Para Pemohon Mengajukan Judicial Review}

Para Pemohon merupakan pihak yang secara langsung mengalami dan merasakan hak konstitusionalnya dirugikan dengan diundangkannya Undang-

20 http://www.koalisiperempuan.or.id/2019/03/18/bersama-memperkuat-bangsa/, diakses pada 13 November 2019.

21 https://solo.tribunnews.com/2017/12/18/kisah-rasminah-perempuan-asal-indramayuyang-dipaksa-menikah-saat-berusia-13-tahun?page=2, diakses pada 13 November 2017

22 https://jateng.tribunnews.com/2019/10/03/dipaksa-nikah-14-tahun-karena-faktorekonomi-maryanti-4-kali-keguguran?page=all, diakses pada 13 November 2019.

23 https://newsmaker.tribunnews.com/amp/2019/10/04/kisah-endang-wasrinah-yangdipaksa-nikah-di-usia-14-tahun-kerap-disuntik-kb-sampai-

demam?page $=2 \&$ ga $=2.205187031 .658545272 .1573661664-1200355030.1570463508$, diakses pada 13 November 2019. 
Undang Perkawinan Tahun 1974 terutama dengan Pasal 7 ayat (1). Hak konstitusional para pemohon yang telah dilanggar dan dirugikan tersebut adalah hak sebagaimana yang telah dijamin dalam Pasal 27 ayat (1) UUD 1945, maka para pemohon memiliki hak konstitusional untuk mendapatkan kedudukan yang sama di mata hukum dalam hal usia pernikahan antara laki-laki dan perempuan.

Konsekuensi dari ketentuan Pasal 27 ayat (1) UUD 1945 tersebut menyatakan, "Segala warga negara bersamaan kedudukannya di dalam hukum dan pemerintahan dan wajib menjunjung hukum dan pemerintahan itu dengan tidak ada kecualinya."24 Ketentuan Pasal 27 ayat (1) menunjukkan bahwa tidak ada pembedaan dalam hak dan kedudukan baik dalam hukum maupun di dalam pemerintahan antara setiap warga negara, atau juga dikenal dengan prinsip "Equality before the Law".

Perbedaan usia antara laki-laki dan wanita pada Pasal 7 ayat (1) UU Perkawinan merupakan sebuah wujud nyata dan konkrit tidak tercapainya persamaan kedudukan di dalam hukum antara laki-laki dan perempuan yang sebagaimana yang diatur pada Pasal 27 ayat (1) UUD 1945 dan UU Perkawinan.

Pasal 7 ayat (1) UU Perkawinan telah menciptakan ketidaksetaraan perlakuan dalam hukum antara laki-laki dan perempuan. Penetapan usia pernikahan 16 tahun bagi anak perempuan, di bawah ambang batas usia anak 18 tahun berdasarkan konvensi hak-hak anak, mengakibatkan terjadinya perbedaan kedudukan hukum termasuk di antaranya kewajiban Negara antara lain untuk melindungi, memenuhi dan menghargai hak-hak anak sesuai UUD 1945.

Perbedaan kedudukan hukum ini mengakibatkan seorang anak perempuan nikah pada usia di bawah 18 tahun, secara otomatis anak perempuan tidak bisa disebut seorang anak, sehingga hak-hak anak yang seharusnya melekat pada dirinya menjadi terampas. Perbedaan ketentuan usia antara laki-laki dan perempuan pada Pasal 7 ayat (1) UU Perkawinan yang semata didasari oleh jenis kelamin merupakan diskriminasi yang sangat nyata. 25

Berdasarkan alasan-alasan hukum dan konstitusional tersebut, para Pemohon memohon kepada Majelis Hakim Mahkamah Konstitusi untuk dapat memutuskan hal-hal sebagai berikut:

a. Menerima dan mengabulkan seluruh permohonan pengujian undang-undang yang diajukan oleh para Pemohon untuk seluruhnya;

24 Majelis Permusyawaratan Rakyat Republik Indonesia. Undang-Undang Dasar Negara Republik Indonesia Tahun 1945., 152.

${ }^{25}$ https://mkri.id/, diakses pada 13 November 2019. 
b. Menyatakan ketentuan Pasal 7 ayat (1) UU nomor 1 Tahun 1974 tentang Perkawinan, sepanjang usia "usia 16 (enam belas) tahun", bertentangan dengan UUD 1945 dan tidak memiliki kedudukan hukum mengikat, sepanjang dibaca "usia 19 (sembilan belas) tahun";

c. Atau apabila Majelis Mahkamah Konstitusi berpendapat lain mohon putusan yang seadil-adilnya.

Secara singkat para Pemohon menyatakan bahwa dengan adanya ketidaksamaan kedudukan dalam hukum dan diskriminasi pada ketentuan usia pernikahan untuk laki-laki dan perempuan telah mengakibatkan kerugian konstitusional baik nyata maupun potensial kepada para Pemohon dan kaum perempuan pada umumnya, karena tidak tercapainya pemenuhan hak-hak atas anak dikarenakan pernikahan di bawah usia 18 tahun dan perbedaan usia pernikahan ini merupakan bentuk diskriminasi yang sangat nyata. Hak-hak anak perempuan yang bersifat fundamental yang telah terampas dan telah dijamin oleh UUD 1945 yang meliputi, hak kesehatan, hak pendidikan, hak untuk tumbuh berkembang, hak untuk bermain dan hak-hak lainnya.

\section{Dasar Pertimbangan Hakim MK Dalam Memutuskan Perkara}

Terhadap dalil para Pemohon yang menyatakan bahwa berlakunya ketentuan Pasal 7 ayat (1) UU No. 1 Tahun 1974 tentang Perkawinan merupakan diskriminasi bagi perempuan karena perbedaan batas usia nikah bagi perempuan dan laki-laki dan telah melanggar hak konstitusionalnya untuk mendapatkan kedudukan yang sama di hadapan hukum sebagaimana telah dijamin dalam Pasal 27 ayat (1) UUD 1945 telah dilanggar oleh adanya pembatas usia minimal pernikahan yang berbeda antara laki-laki dan perempuan.

Pasal 27 ayat (1) UUD 1945 berbunyi: "Segala warga negara bersamaan kedudukannya di dalam hukum dan pemerintahan dan wajib menjunjung hukum dan pemerintahan itu dengan tidak ada kecualinya." 26

Ketentuan Pasal 27 ayat (1) UUD 1945 telah melahirkan norma konstitusi bahwa Pemohon adalah seorang warga negara yang harus disamakan kedudukannya di dalam hukum. Perlakuan tersebut telah menyebabkan terjadinya diskriminasi batas usia minimal atas dasar perbedaan jenis kelamin, melainkan juga perlakuan yang tidak sama terhadap anak dalam pemenuhan dan perlindungan hak asasi anak sebagaimana telah diatur dalam Pasal 28B ayat (2).

26 Majelis Permusyawaratan Rakyat Republik Indonesia, Undang-Undang Dasar Negara Republik Indonesia Tahun 1945, 65. 
Bahwa maksud dan tujuan para Pemohon adalah pengujian konstitusionalitas Undang-Undang, dalam Pasal 7 ayat (1) Undang-Undang No. 1 Tahun 1974 tentang Perkawinan (Lembaran Negara Republik Indonesia Nomor 1, Tambahan lembaran Negara Republik Indonesia Nomor 3019, selanjutnnya disebut UU 1/1974) terhadap Pasal 27 ayat (1) UUD 1945.

Kewenangan MK untuk mengadili permohonan a quo; Berdasarkan Pasal 24C ayat (1) UUD 1945 Pasal 10 ayat (1) huruf a Undang-Undang Nomor 24 Tahun 2003 tentang Mahkamah Konstitusi sebagaimana telah diubah dengan UndangUndang Nomor 8 Tahun 2011 tentang Perubahan Atas Undang-Undang Nomor 24 Tahun 2003 tentang Mahkamah Konstitusi (Lembaran Negara Republik Indonesia Tahun 2011 Nomor 70, Tambahan Lembaran Negara Republik Indonesia Nomor 5226, selanjutnya disebut UU MK), dan Pasal 29 ayat (1) huruf a Undang-Undang Nomor 48 Tahun 2009 tentang Kekuasaan Kehakiman (Lembaran Negara Republik Indonesia Nomor 157, Tambahan Negara Republik Indonesia Nomor 5076), salah satu kewenangan konstitusional Mahkamah adalah mengadili pada tingkat pertama dan terakhir yang putusannya bersifat final untuk menguji Undang-Undang terhadap Undang-Undang Dasar 1945. ${ }^{27}$

Permohonan para Pemohon adalah untuk menguji konstitusionalitas Norma Pasal 7 ayat (1) UU No. 1 Tahun 1974 tentang Pernikahan terhadap UUD 1945, yang menjadi salah satu kewenangan Mahkamah, maka Mahkamah Konstitusi berwenang mengadili permohonan a quo;

Kedudukan hukum (legal standing) para Pemohonan untuk mengajukan Permohonan a quo; Berdasarkan bahwa Pasal 51 ayat (1) UU MK beserta penjelasannya, Pemohon dalam pengujian Undang-Undang terhadap UndangUndang Dasar adalah mereka yang menganggap hak dan/atau konstitusionalnya yang diberikan oleh UUD 1945 dirugikan oleh berlakunya undang-undang yang dimohonkan pengujian, yaitu:

a. Perorangan warga negara Indonesia (termasuk kelompok orang yang mempunyai kepentingan yang sama);

b. Kesatuan masyarakat hukum adat sepanjang masih hidup dan sesuai perkembangan masyarakat dan prinsip Negara Kesatuan Republik Indonesia yang diatur dalam Undang-Undang;

c. Badan hukum dan publik atau privat; atau

27 Undang-Undang Republik Indonesia No. 48 Tahun 2009 Tentang Kekuasaan Kehakiman, di akses 03 Februari 2019. http://UU_no_48_th_2009.pdf. Adobe PDF eBook. 
d. Lembaga negara. ${ }^{28}$

Dengan demikian, Pemohon dalam pengujian undang-undang terhadap UUD 1945 harus menjelaskan terlebih dahulu:

a. Kedudukannya sebagai Pemohon sebagaimana yang di maksud dalam Pasal 51 ayat (1) UU MK;

b. Kerugian hak dan/atau kewenangan konstitusional yang diberikan oleh UUD 1945 yang diakibatkan oleh berlakunya Undang-Undang yang dimohonkan pengujian.

Menimbang mengenai kerugian hak dan/atau kewenangan konstitusional sebagaimana di maksud dalam Pasal 51 ayat (1) UU MK, Mahkamah sejak putusan Nomor 006/PUU-III/2005, tanggal 20 September 2007 serta putusan selanjutnya telah berpendirian adanya 5 syarat yang harus dipenuhi, sebagai berikut:

a. Harus ada hak dan/atau kewenangan konstitusional Pemohon yang diberikan oleh UUD 1945

b. Hak dan/atau konstitusional tersebut dianggap dirugikan oleh berlakunya undang-undang yang dimohonkan pengujian

c. Kerugian hak dan/atau kewenangan konstitusional tersebut bersifat spesifik dan aktual

d. Ada hubungan sebab akibat antara kerugian hak dan/atau kewenangan konstitusional dengan undang-undang yang dimohonkan pengujian

e. Ada kemungkinan bahwa dengan dikabulkannya permohonan, maka kerugian hak dan/atau kewenangan konstitusional yang didalilkan tidak akan atau tidak lagi terjadi.

Menimbang bahwa berdasarkan uraian sebagaimana tersebut pada paragraf di atas, selanjutnya Mahkamah akan mempertimbangkan mengenai kedudukan hukum (legal standing) para Pemohon dalam permohonan a qua sebagai berikut: ${ }^{29}$

a. Pemohon I adalah perorangan warga negara Indonesia, Pemohon I dinikahkan pada saat berusia 14 tahun dengan seorang laki-laki duda yang berusia 37 tahun, alasan pernikahan tersebut karena keadaan ekonomi keluarga. Pernikahan ini menimbulkan beberapa dampak bagi Pemohon:

1) Akibat dari pernikahan ini Pemohon I harus putus sekolah, dengan pendidikan terakhir kelas 2 SMP.

28 Ibid.

${ }^{29} \mathrm{https} / / / \mathrm{mkri.id} /$, diakses pada 13 November 2019. 
2) Setelah menikah kehidupan Pemohon I tidak menjadi lebih baik, tetap berada dalam garis kemiskinan dan akibat dari pendidikan yang tidak diselesaikan, maka Pemohon I tidak dapat mencari pekerjaan yang layak.

3) Akibat pernikahan yang terjadi pada saat Pemohon I massih dalam kategori anak menyebabkan Pemohon I menderita infeksi/iritasi pada organ reproduksi.

b. Pemohon II adalah perorangan negara Indonesia, Pemohon II dinikahkan pada saat usia 14 tahun dengan seorang laki-laki yang berusia 33 tahun dan alasan pernikahan tersebut karena keadaan ekonomi keluarga, orangtua Pemohon II tersebut memiliki hutang kepada calon suaminya. Akibat dari pernikahannya tersebut, Pemohon tidak menyelesaikan pendidikan dasarnya mengalami beberapa kali keguguran.

c. Pemohon III adalah perorangan warga negara Indonesia, Pemohon III dinikahkan pada saat berusia 13 tahun dengan seorang laki-laki yang berusia 25 tahun, alasan pernikahan tersebut karena keadaan ekonomi keluarga. Pemohon III menikah setelah tamat sekolah dasar, namun perorangan III tidak dapat mengambil ijazah sekolah dasarnya karena keterbatasan ekonomi. Pemohon III melahirkan anak pertamanya pada usia 14 tahun. Sepanjang hidupnya Pemohon III telah melakukan pernikahan sebanyak 4 kali, dan 2 di antaranya dilakukan pada saat Pemohon III masih dalam usia anak dan pernikahan ini dilakukan karena alasan ekonomi.

Berdasarkan seluruh uraian di atas para Pemohon dalam menjelaskan kedudukan hukumnya sebagaimana diuraikan di atas, dalam kualifikasi tersebut, para Pemohon telah jelas menerangkan hak-hak konstitusionalnya yang dianggap dirugikan oleh berlakunya norma undang-undang yang dimohonkan pengujian dan kerugian yang dianggap dialami oleh para Pemohon sehingga apabila permohonan dikabulkan maka kerugian di maksud tidak akan terjadi, dengan demikian para Pemohon memiliki kedudukan hukum untuk mengajukan $a$ quo.

\section{Amar Putusan}

Amar putusan Keputusan Mahkamah Konstitusi Nomor 22/PUU-XV/2017 terhadap Pasal 7 ayat (1) Undang-Undang Perkawinan mengadili dan menyatakan:30 a. Mengabulkan permohonan para Pemohon untuk sebagian;

${ }^{30}$ https://mkri.id/, diakses pada 13 November 2019. 
b. Menyatakan Pasal 7 ayat (1) sepanjang usia "usia 16 (enam belas) tahun" Undang-Undang Nomor 1 Tahun 1974 Tentang Pernikahan (Lembaran Negara Republik Indonesia Nomor 1, Tambahan Lembaran Negara Republik Indonesia Nomor 3019) bertentangan dengan Undang-Undang Dasar Negara Republik Indonesia Tahun 1945 dan tidak mempunyai kekuatan hukum mengikat;

c. Menyatakan ketentuan Pasal 7 ayat (1) Undang-Undang Nomor 1 Tahun 1974 tentang Pernikahan (Lembaran Negara Republik Indonesia Tahun 1974 Nomor 1, Tambahan Lembaran Negara Republik Indonesia Nomor 3019) masih tetap berlaku sampai dengan dilakukan perubahan sesuai dengan tenggang waktu sebagaimana yang telah ditentukan dalam putusan ini;

d. Memerintahkan kepada pembentuk Undang-Undang dalam jangka waktu paling lama tiga (3) tahun melakukan perubahan terhadap Undang-Undang Nomor 1 Tahun 1974 tentang Pernikahan (Lembaran Negara Republik Indonesia Tahun 1974 Nomor 1, Tambahan Lembaran Negara Republik Indonesia Nomor 3019), khususnya berkenaan dengan batas minimal usia pernikahan bagi perempuan;

e. Memerintahkan pemuatan Putusan ini dalam Berita Negara Republik Indonesia sebagaimana mestinya;

f. Menolak permohonan para pemohon untuk selain dan selebihnya.

\section{E. Pembahasan}

\section{Analisis Alasan Pemohon Mengajukan Uji Materi}

Hukum Islam turut andil dalam menyelesaikan kesamaan kedudukan manusia antara laki-laki dan perempuan, tidak ada perbedaan sama sekali. Kedudukan segala hak yang dibutuhkan antara laki-laki dan perempuan adalah rata. Allah swt menciptakan makhluk-Nya tanpa ada perbedaan walaupun dibedakan dengan jenis kelamin saja, tetapi kedudukannya tetaplah sama.

Diskriminasi yang selalu diagung-agungkan para pembela perempuan salah menafsirkan kedudukan ini, yang mengatakan bahwa laki-laki selalu diutamakan dari pada perempuan. Islam hadir untuk membantah tafsiran tersebut dengan firman Allah swt Q.S an-Nisa' [4]: 32 bahwa manusia dilarang saling iri hati :

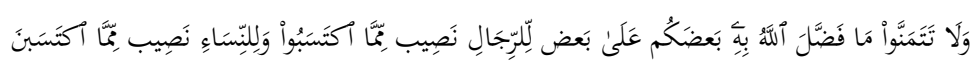

Ayat ini tidak mengandung diskriminasi dalam berbagai macam tugas dan fungsi sebagai manusia. Karena dalam Islam tidak ada saling menghasut, 
menjatuhkan dan saling membongkar kekurangan antara laki-laki dan perempuan. ${ }^{31}$ Syariat Islam telah menetapkan berbagai aktivitas dan kedudukannya sebagai hamba Allah. Islam memandang laki-laki dan perempuan dasarnya adalah sama tanpa perbedaan dan keistimewaan di antara satu sama lain. ${ }^{32}$

Hak pendidikan yang berjalan 12 tahun dalam pendidikan negara Indonesia adalah wajib untuk segala anak perempuan maupun laki-laki di Indonesia. Hak kesehatan untuk melindungi segala penyakit yang datang kepada manusia di Indonesia juga diatur oleh negara Indonesia. Hak melindungi anak dari eksploitasi anak di atur oleh negara Indonesia. Usia pernikahan di negara-negara disesuaikan dengan keadaan dan potensi, kemampuan, kesehatan ketika ingin menikah.

Indonesia mengambil batas usia 16 tahun untuk perempuan dan 19 tahun untuk laki-laki karena adanya kemashlahatan bersama, karena perempuan lebih cepat pertumbuhannya dan lebih cepat haid atau lebih cepat baligh dan dewasa daripada laki-laki. Diputuskannya batas usia nikah tersebut adalah untuk menjaga keselamatan dan kesehatan setiap perempuan dan laki-laki.

Kaidah fikih adalah (جلب المصالح أولى من درأ المفاسد) memiliki arti mengambil kemashlahatan dan menghindari kemudharatan, dalil tersebut diambil dari maqashid syari'ah dalam melindungi jiwa dan keturunan dalam kaitan diskriminasi hak-hak perempuan dalam melakukan pernikahan.

Keempat pernyataan para Pemohon dalam mengajukan uji materi pasal 7 ayat (1) tersebut dan kaitannya dengan paparan penulis di atas maka tidak setiap pengajuan para Pemohon terhadap kesamaan setiap hak sebenarnya harus melihat kemaslahatan terlebih dahulu dalam bertindak.

Apabila seorang anak perempuan yang sehat dan bisa melahirkan dan tidak mementingkan pendidikan karena tidak bisanya menanggung beban biaya sekolah dan hadirnya laki-laki sang pelamar adalah orang yang dia setujui untuk menikah dengannya maka kemaslahatannya adalah anak perempuan tersebut haruslah menikah walaupun umur anak perempuan tersebut kurang dari batas usia yang telah ditentukan UU tetapi telah balig dan tidaklah dikatakan eksploitasi anak jika anak tersebut lebih siap menikah daripada belajar.

Akan tetapi apabila anak perempuan tersebut dipaksa untuk menikah dengan seorang lelaki yang tidak disukai karena kemiskinan yang menghimpit keluarga dan anak perempuan tersebut belum siap mental untuk berkeluarga,

\footnotetext{
31 Sayyid Quthb, Fi Zhilalil Qur'an, trans. As'ad Yasin et.al., 347.

32 Siti Muslikhati, "Feminisme Dan Pemberdayaan Perempuan Dalam Timbangan Islam, 116.

${ }^{33}$ https://www.hujjah.net/mencegah-mafsadat-menuai-maslahat// diakses pada 13 November 2019
} 
kesehatan yang masih tidak pantas untuk berjima' dengan suami dan melahirkan, dan tidak setuju untuk menikah karena inginnya menuntut ilmu maka anak perempuan tersebut tidak diwajibkan menikah hingga dia mampu untuk menikah dengan stabilnya kesehatan, siapnya berumah tangga dan siap menerima tanggung jawab sebagai istri dan ibu.

Apabila dipaksakan untuk menikah maka resiko anak perempuan tersebut akan tersiksa karena tidak bisanya menanggung beban yang berat dan ketidaksiapan berumah tangga dan akan ada kerusakan terjadi yaitu anak perempuan akan kesakitan karena keguguran atau melahirkan anak yang kurang sehat dan suami yang tidak membantu anak perempuan tersebut dalam hal tanggung jawab.

Maka uraian penulis di atas adalah sebuah diskriminasi hak-hak anak perempuan yang tidak terlanggar karena pernikahan yang terpaksa tanpa persetujuan anak perempuan untuk siap menikah akan tetapi tidak dikatakan diskriminasi apabila anak perempuan siap menerima pernikahan.

\section{Analisis Pertimbangan Mahkamah Konstitusi Dalam Putusan}

Al-Qur'an dan hadits merupakan rujukan ummat Islam dalam menentukan hukum karena keduanya meletakkan dasar dan prinsip umum dalam menentukan suatu hukum. Indonesia adalah negara hukum yang karenanya setiap warga negara wajib menaatinya, salah satu hukum Indonesia adalah diundang-undangkannya sebuah Undang-Undang Perkawinan dan kompilasi Hukum Islam dan yang di maksud peneliti disini adalah Undang-Undang batas usia nikah bagi laki-laki dan perempuan.

Mahkamah Konstitusi (MK) dalam menghadapi pengujian undang-undang yang diajukan warga negara yang merasa bahwa UU Pernikahan tentang batas usia nikah bagi perempuan merupakan suatu diskriminasi dalam hak perempuan. Hakim Konstitusi menerima pernyataan tersebut dalam putusan nomor 22/PUU-XV/2017 berdasarkan melindungi hak-hak perempuan khususnya anak perempuan.

Islam menentukan batas usia untuk seseorang menikah dengan kedewasaan atau balig dan berakal, kedewasaan yang di maksud adalah apabila seorang laki-laki telah mengalami mimpi basah dan seorang perempuan telah mengalami haid. ${ }^{34}$ Berakal yang di maksud adalah bisa membedakan jalan baik atau buruk yang akan ditempuhnya.

${ }^{34}$ Dadang Hawari, al-Qur'an Ilmu Kedokteran Jiwa dan Kesehatan, 252. 
Islam mensyariatkan seseorang mencari pasangan hidup sesuai yang dia sukai dan tanpa ada paksaan di dalamnya. Islam mensyariatkan seorang calon suami maupun calon istri untuk mencari pasangan hidupnya sesuai dengan kategori atau syarat yang telah ditentukan. Ketika anak perempuan belum baligh dan ingin dinikahi oleh seorang yang dewasa dan anak tersebut tidak menyukai orang yang dijodohkan kepadanya maka persetujuan anak perempuan tetap dibutuhkan agar agar anak perempuan tersebut tidak tertekan setelah menikah.

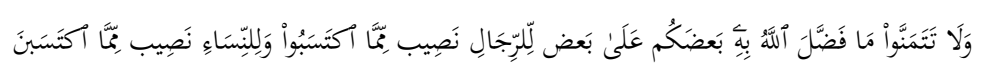

Ayat ini tidak mengandung diskriminasi dalam berbagai macam tugas dan fungsi sebagai manusia. Karena dalam Islam tidak ada saling menghasut, menjatuhkan dan saling membongkar kekurangan antara laki-laki dan perempuan. ${ }^{35}$ Syariat Islam telah menetapkan berbagai aktivitas dan kedudukannya sebagai hamba Allah. Islam memandang laki-laki dan perempuan dasarnya adalah sama tanpa perbedaan dan keistimewaan di antara satu sama lain. ${ }^{36}$

Kedudukan perempuan dan laki-laki adalah sama dihadapan tuhannya, tidak ada perbedaan dalam hal apapun sebagaimana halnya pernikahan yang dibatasi oleh pemerintah dalam UUP Pasal 7 ayat (1) tidak ada permasalahan dalam hal usia. Dalil penguat adalah درأ الفاسد من اولى جلب المصالحartinya mengambil kemashlahatan dan menghindari kemudaratan, dalil tersebut diambil dari maqashid syariah dalam melindungi jiwa dan keturunan.

Menurut penulis pernikahan di bawah batas usia nikah boleh saja apabila ada kemashlahatan di dalamnya dan ada persetujuan kedua calon mempelai tanpa paksaan dan mereka merasa sanggup menanggung resiko kehamilan dan kelahiran keturunannya kelak karena kondisi calon mempelai perempuan atau "anak perempuan" telah siap untuk melahirkan dan menanggung bebannya.

Apabila calon istri tidak setuju karena tidak bisanya melahirkan di usia muda dan belum bisa mengatur dan menjalankan hak istri maka pernikahan tersebut tidak boleh terjadi karena kerusakan akan terjadi. Jika pernikahan tersebut dipaksakan karena orangtuanya tidak ingin anaknya menjadi beban keluarga dan dari hasil pernikahan tersebut si istri atau "anak perempuan" mengalami penyakit maka hal ini tidak dibenarkan dalam syariat Islam.

Kaitan paparan penulis di atas dengan putusan MK adalah bahwa MK tidak berhak menaikkan batas usia yang terdapat pada UUP No. 1 Tahun 1974 Pasal 7 ayat (1) karena apabila usia 16 tahun disetarakan dengan usia laki-laki karena 
diskriminasi hukum maka akan semakin banyak kaum perempuan yang akan menikah di usia 19 tahun di saat dia telah melakukan zina atau memiliki anak tanpa menikah.

Sebagaimana negara Indonesia yang memiliki anak remaja yang setiap tahunnya melakukan tindakan berisiko dengan masa depan terhadap kesehatan seks pranikah. Jika batas usia perempuan dinaikkan maka akan semakin banyaklah kemaksiatan merajalela di Indonesia sebagaimana yang disebutkan oleh Riset Kesehatan Indonesia bahwa anak perempuan berumur 15-19 tahun telah melakukan seks pranikah.

Putusan MK ini bukan merupakan diskriminasi karena tidak setaranya antara perempuan dan laki-laki hingga hak konstititusionalnya dilanggar akan tetapi apabila dinaikkan usia nikah perempuan maka akan menjadi sebuah kerusakan yang semakin besar kepada remaja yang telah baligh serta siap mental, siap psikologi dan kesehatan serta berfikir dewasa apabila keinginan menikah tidak tercapai karena adanya kenaikan usia yang telah ditetapkan MK.

\section{F. Kesimpulan}

Berdasarkan hasil penelitian yang peneliti lakukan tentang putusan mahkamah konstitusi nomor 22/PUU-XV/2017 tentang batas usia nikah bagi perempuan, maka peneliti akan memaparkan beberapa kesimpulan.

Pertama adalah adanya beberapa alasan Pemohon mengajukan uji materi pada Pasal 7 ayat (1) Tahun 1974 tentang Perkawinan, yaitu; Menimbulkan perbedaan kedudukan hukum dan diskriminasi terhadap anak perempuan dalam hak kesehatan; Menimbulkan perbedaan kedudukan hukum dan diskriminasi terhadap anak perempuan dalam hak pendidikan; Menimbulkan perbedaan kedudukan hukum dan diskriminasi terhadap anak perempuan dalam eksploitasi anak; Menimbulkan perbedaan kesetaraan batas usia menimal nikah pada laki-laki dan perempuan di berbagai negara.

Kedua adalah beberapa pertimbangan mahkamah konstitusi dalam putusan nomor 22/PUU-XV/2017 tentang batas usia nikah bagi perempuan adalah bahwa terhadap dalil permohonan para Pemohon sepanjang ketentuan Pasal 7 ayat (1) UUP No. 1 Tahun 1974 telah menimbulkan diskriminasi atas dasar jenis kelamin atau gender yang berdampak terhadap tidak terpenuhinya hak anak perempuan sebagai bagian dari hak asasi manusia yang dijamin dalam UUD 1945 adalah beralasan menurut hukum untuk sebagian. Sedangkan dalam hukum Islam pernikahan tidak ada batas usia dan tidak ada diskriminasi di dalamnya karena 
pernikahan dibolehkan apabila anak perempuan telah balig dan siap menikah serta setuju dengan pernikahan tersebut walaupun usia masih dini. 


\section{Daftar Pustaka}

Amir. Nuruddin, dan Azhari Akmal Taringan. Hukum Perdata Islam Indonesia: Studi Kritis Perkembangan Hukum Islam Dari Fikih, UU/1974 Sampai KHI. Jakarta: Prenadamedia Group, 2016), Cet. ke-6.

an-Nawawi, Muhyiddin. Shohih Muslim (Beirut: Darul Ma'rifah, 1998), No. 3434.

Hawari, Dadang.al-Qur'an Ilmu Kedokteran Jiwa dan Kesehatan. Jakarta: Bhakti Prima Yasa, 1996.

Hukum Online, “Undang-Undang Republik Indonesia Nomor 35 Tahun 2014 Tentang Perubahan Atas Undang-Undang Nomor 23 Tahun 2002 Tentang Perlindungan Anak," diakses pada 07 Januari 2019. www.hukumonline.com. Adobe PDF eBook.

Husain, Muhammad. Fiqh Perempuan. Yogyakarta: Liks, 2001. Google Book.

Majelis Permusyawaratan Rakyat Republik Indonesia, Undang-Undang Dasar Negara Republik Indonesia Tahun 1945, 65.

Muhammad, Abdullah bin. Luhbatut Tafsir Min Ibni Katsir. trans M. Abdul Ghoffar. Jakarta: Imam Syafi'i, 2016, Cet. 9.

Muslikhati, Siti. "Feminisme Dan Pemberdayaan Perempuan Dalam Timbangan Islam, 116.

Muthiah, Aulia. Hukum Islam Dinamika Seputar Hukum Keluarga,63.

Quthb, Sayyid. Fi Zhilalil Qur'an, trans. As'ad Yasin et.al. 347.

Radar Cirebon. "MUI Sebut Putusan MK Menimbulkan Polemik." diakses pada 20 Desember 2018.http://www.radarcirebon.com. Adobe PDF eBook.

Ridha, Muhammad Rasyid,Tafsir al-Manar Juz I. Mesir: al-Manar, 2000.

Syafruddin, Amir. Hukum Perkawinan Islam di Indonesia. Jakarta: Prenamedia Group, 2014, Cet. Ke-5.

Undang-Undang Republik Indonesia No. 48 Tahun 2009,“Kekuasaan Kehakiman,” di akses 03 Februari 2019. http://UU no 48 th 2009.pdf. Adobe PDF eBook.

Uwaidah, Kamil Muhammad. al-Jami' fii Fiqhi an-Nisa', trans. M. Abdul Ghoffar Jakarta: Pustaka al-Kautsar, 2012. 